[Professional and pedagogical culture of the teacher]. Moskva.

7. Karachevceva, A. P. (2003). Formirovanie metodicheskoj kultury uchitelya nachalnyh klassov na pervoj stupeni pedagogicheskogo obrazovaniya. [Formation of methodological culture of primary school teachers at the first stage of pedagogical education]. Kursk.

8. Pavlenko, O. O. (1998). Pro zmist hotovnost studentiv pedvuzu do vykorystannia natsionalnykh tradytsii $u$ vykhovanni shkoliariv. [On the content of the readiness of university students to use national traditions in the education of schoolchildren]. Dnipropetrovsk.

9. Pavlenko, E. A. (1997). Formirovanie gotovnosti studentov pedvuza $k$ ispolzovaniyu nacionalnyh tradicij $v$ vospitanii shkolnikov. [Formation of the readiness of pedagogical university students to use national traditions in the education of schoolchildren]. Krivoj Rog.

10. Pavlenko, O. O. (2016). Formuvannia metodychnoi kultury vykladacha ekonomiky: teoretykometodolohichnyi aspect. [Formation of methodical culture of the teacher of economics: theoretical and methodological aspect]. Kryvyi Rih.

11. Plehanova, L. A. (2012). Vnutriorganizacionnoe obuchenie kak sredstvo razvitiya metodicheskoj kultury prepodavatelej uchrezhdeniya dopolnitelnogo professionalnogo obrazovaniya. [Intra-organizational training as a means of developing the methodological culture of teachers of an institution of additional professional education]. Chelyabinsk.

\section{ВІДОМОСТІ ПРО АВТОРА}

КАЙДА Надія Олександрівна - викладач кафедри іноземної філології та перекладу Київського національного торговельноекономічного університету.
Наукові інтереси: проблеми формування методичної культури викладачів ЗВО.

\section{ПАСИК-КОСАРЕВА}

Наталія

Олександрівна - викладач кафедри іноземної філології та перекладу Київського національного торговельно-економічного університету.

Наукові інтереси: методична культура викладача іноземної мови та іiі формування в процесі професійної підготовки.

РОЗУМ Антоніна Петрівна - старший викладач кафедри іноземної філології та перекладу Київського національного торговельноекономічного університету.

Наукові інтереси: формування методичної культури викладачів ЗВО

INFORMATION ABOUT THE AUTHOR

KAIDA Nadia Oleksandrivna - Lecturer of the Department of Foreign Philology and Translation, Kyiv National University of Trade and Economics.

Circle of scientific interests: problems of formation of methodological culture of university teachers.

PASYK-KOSARIEVA Nataliia Oleksandrivna - Lecturer of the Department of Foreign Philology and Translation, Kyiv National University of Trade and Economics.

Circle of scientific interests: foreign language teacher's methodological culture and it's formation in the process of professional training.

ROZUM Antonina Petrivna - Senior Lecturer of the Department of Foreign Philology and Translation, Kyiv National University of Trade and Economics.

Circle of scientific interests: formation of methodological culture of university teachers.

Стаття надійшла до редакиії 18.03.2021 p.

UDC 378

DOI: 10.36550/2415-7988-2021-1-194-213-217

LOMAKINA Larysa Volodymyrivna Senior Lecturer of the Department of English for Engineering №1 National Technical University of Ukraine

«Igor Sikorsky Kyiv Polytechnic Institute» ORCID:https://orcid.org/0000-0002-3449-8121 e-mail: 1lv85@ukr.net

\title{
STUDENTS' INDEPENDENT STUDY AS A COMPONENT IN THE PROFESSIONAL TRAINING OF FUTURE SPECIALISTS
}

Statement and substantiation of the relevance of the problem. In the current labor market conditions, the requirements for the professional competence of graduates are growing. It determines qualitatively new forms and methods of higher education aimed at creating a holistic system of continuing education, expanding the sphere of students' independent activity and form self-organization and self-education skills. As a priority, the educational system considers the interests of the individual, adequate to modern trends in social development. Gradually, but steadily, higher education is moving from transmitting information to managing educational and cognitive activities, forms students' independent study skills. If the previous concepts were planned for acquiring knowledge, skills and habits, then the modern educational system focuses on the formation of competencies, the 
independent knowledge search and the need for their improvement. Therefore, the students' cognitive independence is one of the decisive prerequisites for improving the quality of training of specialists in the modern world. According to the Regulations on the organization of the educational process in higher educational establishments, students' independent study is the main means of mastering the learning material in the time free from compulsory education.

The professional growth of future specialists and their competitiveness in the labor market depend to a greater extent on how future specialists will solve non-standard tasks, plan and implement the results of their activities. Thus, students should not only master knowledge and skills, acquire habits, gain experience, but also be able to develop their self-organization, the willingness to independently process information, the ability not only to develop an individual trajectory of self-learning, but also to constantly follow it [7, p. 85].

Moreover, it should be noted that there is a contradiction between the need to increase the proportion of hours for students' independent study and, as consequently, reduce the classroom workload, and the lack of students' skills and habits to work independently with a high efficiency.

To implement the above-mentioned changes in the educational system and optimize the educational process, it is necessary to change the students' approach to learning. Firstly, to increase the level of students' organization, namely, to teach them to divide work into stages, with setting goals and objectives in each period of activity, to allocate time for performing specific tasks, to organize their workplace.

Secondly, to motivate students to move from the traditional, familiar form of learning, where the teacher offers information, and students process it, to an independent study, where students independently find a solution to the problem, test it, and only after that present it to the audience. This approach will bring up a responsible and curious student, who will later become a highly qualified specialist.

The formation of an internal need for selflearning becomes both a requirement of time and a condition for the realization of personal potential. Therefore, one of the purposes of professional training of future specialists is the necessity to give them a thorough fundamental knowledge, on the basis of which they could study independently in the direction they need.

Independent learning is a type of mental activity in which a student independently (without outside help) learns a topic, solves a problem or performs a task based on knowledge gained from textbooks, books, lectures, practical or laboratory classes.

Issues of independent study are not fundamentally new for domestic higher education.

By self-study activity we mean a type of activity that is able to orient the students to selfimprovement and self-development of professional knowledge and skills that will ensure the formation of their professional competencies. Independent extracurricular learning is considered as a means that forms the student's cognitive abilities, in the process of which the student gradually turns into a self-learning subject.

Analysis of recent research and publications. Researchers dealing with the problem of organizing students' independent study put different meanings into this concept.

Thus, the concept of «independent study» is interpreted as: the independent search for the necessary information, the acquisition of knowledge, the use of this knowledge to solve educational, scientific and professional problems [1]; activity consists of many elements: creative perception and comprehension of learning material during a lecture, preparation for classes, exams, credits, writing of course and thesis works [5]; types of individual, group cognitive activity of students in classes or outside of the classes without direct teachers' guidance, but under their supervision [6]; a system of measures aimed at raising activity and independence as personality characteristics, at acquiring skills and habits for rational obtaining of useful information [3].

A number of authors [2] consider it as a system of organizing pedagogical conditions that ensure the management of educational activities without the presence of a teacher. In some approaches, independent study is identified with self-education.

As can be clearly seen from the above definitions and interpretations, independent work is considered, on the one hand, as a type of study that stimulates activity, independence, cognitive interest, and as a basis for self-education, the impetus for further development of professional qualifications, and on the other hand - as a system of measures or pedagogical conditions that provide guidance for students' independent activities.

Thus, the students' independent study is a specific type of training, the main purpose of which is the formation of learner's independence, the formation of his skills, knowledge and habits; it is carried out directly through the content and methods of all types of training. The organization and provision of the necessary conditions for the implementation of students' independent study in special disciplines is a necessary element of future specialists' training. 
Despite the thorough research of this problem, today the issue of organizing independent study and the readiness of students for its implementation is quite acute. Slipenka and Kots emphasize that a large percentage of students are dissatisfied with the forms of organizing of their independent learning at the university. They determine the positive aspects in the organization of independent study: learning new things through obtaining additional knowledge, forming their own opinions based on expanding the range of their interests and knowledge, deep assimilation of the material, development of individual qualities, etc. But, at the same time, many students have certain difficulties: lack of skills to work independently, as well as, to combine theoretical material with practical actions [8].

The purpose of the article is to acquaint with the forms and methods of students' independent study, to consider the specifics and problems of its organization, to convey the importance of independent learning in the formation of professional competence of highly qualified specialists.

The main material of the study. The main characteristics of self-educational activities: selfselection of material; definition of strategy and tactics of its studying; self-study; solving problems and cognitive tasks that arise when there are different points of view on the same subject; independent overcoming of contradictions; the formation of one's own vision of this subject, one's own worldview; self-change $[4$, p. 50].

In the modern world, the sources and speed of obtaining information by students are fundamentally different from the traditional printed publications stored in the library. Therefore, the main task of the teacher is to teach the students to independently select from the huge flow of information that information which will improve their professional knowledge and form necessary competencies in their future professional activity.

From the point of view of the actualization of self-educational activity, independent learning performs the function of a stalker, because this activity is able to develop students' motivating attitude to independently systematically acquire knowledge and develop skills to navigate the flow of information when solving new cognitive tasks.

Independent extracurricular study is usually understood as any learning organized to fulfill a given didactic goal in a specially allotted time: knowledge search, its comprehension, consolidation, formation and development of skills and habits, knowledge generalization and systematization. Thus, solving the problems of modern education is impossible without increasing the role of students' independent study, strengthening the responsibility of teachers for the development of independent learning skills, for stimulating students' professional growth. The technology of organizing students' independent study should be phased and justified. Its effective implementation requires the readiness of the teaching staff to undertake such activities.

The readiness of the teaching staff should be understood as the ability of teachers to highlight the most important aspects of the independent learning course, which the students will constantly use in their future professional activities. At the same time, teachers must have organizational skills. The teacher's activity in organizing students' independent study involves the creation of optimal conditions for managing and self-governing the process of personal and professional development when students interact with information, use this information and gain new knowledge.

Thus, the main task of independent study is the formation of students' cognitive independence, which is directly related to their formation as professionals. Therefore, the level indicator of students' cognitive independence will be their professional skill, the students' readiness to acquire and replenish professional knowledge, the formation of professional competencies, the formulation and solution of professional tasks without teacher's guidance.

Let us consider examples of extracurricular independent study, as a result of which students independently select material, work with information, prepare statements, and the role of the teacher is to determine the correctness of the student's use of discipline fundamental knowledge acquired earlier in their practical activities.

The first example is the use of Moodle virtual learning environment. Moodle (Modular Object-Oriented Dynamic Learning Environment) is a site content management system specially designed by teachers for online learning courses. It is focused on organizing interaction between the teacher and students for both classroom and students' extracurricular independent study.

In the National Technical University of Ukraine «Igor Sikorsky Kyiv Polytechnic Institute» it was decided to test first-year students to determine the level of foreign language proficiency for the purpose of students' distribution on language groups of different levels. After testing and analyzing the results, students were assigned to 3 levels (C - PreIntermediate, B - Intermediate and A - UpperIntermediate). For each level, an appropriate 
language textbook was selected and distance support for classes in the discipline «Foreign Language - I» (General English) on the Moodle platform was created.

Before the creation of such courses, goals and approaches of teaching a foreign language were determined in accordance with the level of students' knowledge, and resources and tools for students' active learning were selected and prepared. Courses are created on the basis of modular/block form of distribution of educational information, and the combination of modules provides a certain degree of flexibility and freedom in the selection and assembly of the required educational material, both for classroom and extracurricular students' learning. The virtual learning environment Moodle significantly increases the effectiveness of foreign language teaching in non-linguistic universities, since the resources of this environment are quite diverse. In addition, it allows not only teachers to carry out high-quality continuous control of students' independent study but also the students to independently control their learning process. Students who have missed classes, or who want to deal with a complex topic a second time, get an additional opportunity to study the lesson material, which also increases the effectiveness of learning.

Thus, once again we come to the conclusion that independent learning is one of the ways to increase the effectiveness of the language training of future engineer specialists. It is performed in extracurricular or classroom time on the assignment and with the methodological teacher's guidance, but without his direct participation (or with the partial direct participation of the teacher, leaving the leading role for the student).

The organization of students' independent study sets and solves the following tasks: 1) work with the review material (consolidation, generalization, and repetition); 2) the formation of research skills; 3) individualization of educational and scientific-cognitive activities; 4) the formation of readiness for lifelong selflearning.

The second example of extracurricular independent learning is training of technical university students to summarize primary documents in their main specialty. Students of «Igor Sikorsky Kyiv Polytechnic Institute» during the period of training in English for Professional Purposes acquire the skills of oral, written communication and abstracting of primary professionally-oriented documents.

The purpose of written abstracting is the ability to independently analyze various points of view, phenomena, facts and events. The aim of the abstract is the prompt and systematic presentation of relevant scientific and technical information in a curtailed form based on its semantic processing. The abstract should concisely convey the main information contained in the original publication. It should be composed in such a way that in the shortest possible time it would be possible to draw from it basic and essential information on the interest issue.

The main requirements for the composition of the abstract are objectivity (selection and presentation of information only from the original text), completeness (reflection of all essential ideas and provisions that make up the main scientific and thematic content of the original publication) and adequate style (unified system of using key terminology, terminological phrases and linguistic means taken from the original source). The author of the abstract should not make any changes or additions to the essence of abstracted work, enter into polemics with the author, state his own point of view, evaluate the facts, draw conclusions. It should be remembered that great importance in abstracting is given to the self-collected material's systematization and classification. Moreover, it is necessary to present text material in chronological order, trying to reveal the main idea of a particular issue.

The task of oral abstracting is to analyze (not retell) the information presented in the text with the expression of one's own attitude to the problem. Thus, students learn to make abstracting based on original English-language publications, highlighting the main problem indicated in the article, analyzing the solution to the above problem and expressing first the author's opinion and, finally, their own opinion on this problem.

Due to the fact that modernity makes increasingly higher demands on the practical knowledge of a foreign language in everyday communication and in the professional sphere, one of the tasks of teaching English is to develop students' skills to independently work with original professionally-oriented English-language literature, and, in particular, to develop skills of oral and written text abstracting.

Therefore, meeting the needs of future specialists in self-mastering of abstracting skills and habits leads to a significant increase of the knowledge level of professionally-oriented foreign language and person's self-actualization. That is why it is necessary to apply this type of extracurricular independent work of students in the practice of teaching a foreign language.

Conclusions and prospects for further researches of directions. In conclusion, it should be emphasized that organizing students' independent study at the university is a complex and multifaceted process. It includes both the formation of self-motivation and selforganization of future specialist, and the readiness of the teaching staff for this type of 
activity.

The results of the practical activities of teaching a foreign language at Igor Sikorsky Kyiv Polytechnic Institute showed that the independent learning of students, organized taking into account the pedagogical conditions, gives a significant positive effect in the formation of professional competence, that is, it is an important component in the professional training of future specialists.

Among the promising areas in the organization of scientific research on this issue, we should pay attention to those of them, the scientific research subject of which is the choice of forms and methods of teaching, and the choice of highly effective types of students' independent study, taking into account the specifics of the professional development of students.

\section{СПИСОК ДЖЕРЕЛ}

1. Архангельский С., Михеев, В Теоретические основы научной организации педагогических исследований. Москва: Знание, 1976. $27 \mathrm{c}$.

2. Граф В., Ильясов I., Ляудис В. Основы организации учебной деятельности и самостоятельной работы студентов. М., 1981.79 с.

3. Иоганзен Б. Научная организация самостоятельной работы студентов. Томск, 1970. $40 \mathrm{c}$.

4. Миняева Н. Самообразование студента в вузе в свете ключевых идей гуманитарных наук. Bысшее образование сегодня. 2010. Вып. 7. С. 4954.

5. Молибог А. О планировании самостоятельной работы студентов. Педагогика высшей школы. Мн.: Высшая школа. 1997. Вып. 2. C. 138-142.

6. Низамов Р. Дитактические основы активизации учебной деятельности студентов. Казань: КГУ, 1975. 130 с.

7. Шогенова Ф. Развитие системы исследовательской деятельности студентов в новых социальных условиях. Педагогика. 2010. Вып. 9. C. $89-102$.

8. Сліпенька O., Коц I. URL: http://conf.vstu.vinnica.ua/humed/2006/txt/06sopsrs.ph p (дата звернення:15. 12. 2020).

\section{REFERENCES}

1. Arkhangelskiy, S., Mikheyev, V. (1976). Teoreticheskiye osnovy nauchnoy organizatsii pedagogicheskikh issledovaniy. [Theoretical foundations of the scientific organization of pedagogical research]. Moscow.

2. Graf, V., Iliasov, I., Lyaudis, V. (1981). Osnovy organizatsii uchebnoy deyatelnosti $i$ samostoyatelnoy raboty studentov. [Fundamentals of educational activities and students' independent study]. Moscow.

3. Ioganzen, B. (1970). Nauchnaya organizatsiya samostoyatelnoy raboty studentov. [Scientific organization of students' independent study].Tomsk.

4. Minyayeva, N. (2010). Samoobrazovaniye studenta $v$ vuze $v$ svete klyuchevykh idey gumanitarnykh nauk. [Self-education of a student at a university in the light of key ideas of Human Sciences].

5. Molibog, A. (1997). O planirovanii samostoyatelnoy raboty studentov. [About planning students' independent study].

6. Nizamov, R. (1975). Ditakticheskiye osnovy aktivizatsii uchebnoy deyatelnosti studentov. [Didactic basis for enhancing the educational activities of students]. Kazan.

7. Shogenova, F. (2010). Razvitiye sistemy issledovatelskoy deyatelnosti studentov $v$ novykh sotsialnykh usloviyakh. [Development of the system of students' research activities in new social conditions]. URL:

8. Slipenka, O., Kots, I. (2006). available at http://conf.vstu.vinnica.ua/humed/2006/txt/06sopsrs.ph $\mathrm{p}$ (accessed 15. 12. 20200).

\section{ВІДОМОСТІ ПРО АВТОРА}

ЛОМАКІНА Лариса Володимирівна старший викладач кафедри англійської мови технічного спрямування №1 Національного технічного університету України «Київський політехнічний інститут імені Ігоря Сікорського».

Наукові інтереси: інформаційнокомунікаційні технології в освіті, методи навчання іноземних мов на нелінгвістичних факультетах.

\section{INFORMATION ABOUT THE AUTHOR}

LOMAKINA Larysa Volodymyrivna - Senior Lecturer of the Department of English for Engineering №1 of National Technical University of Ukraine «Igor Sikorsky Kyiv Polytechnic Institute».

Circle of scientific interests: information and communication technologies in education; methods of foreign language teaching at the non-linguistic faculties.

Стаття надійшла до редакиії 27.04.2021 p. 